\title{
Metabolic and Endocrine Changes in Response to Endotoxin Administration With or Without Oral Arginine Supplementation
}

\author{
B. R. Hüsler, ${ }^{1}$ and J. W. Blum \\ Division of Animal Nutrition and Physiology, Faculty of Veterinary Medicine, \\ University of Berne, $\mathrm{CH}-3012$ Berne, Switzerland
}

\begin{abstract}
This study was performed to investigate blood metabolite, tumor necrosis factor- $\alpha$, and hormone responses to intravenous administration of lipopolysaccharides $(2$ $\mu \mathrm{g}$ of endotoxin of Escherichia coli O26:B6/kg body weight at times of feeding) in veal calves orally supplemented with arginine $(0.25 \mathrm{~g} / \mathrm{kg}$ of body weight twice daily for $4 \mathrm{~d}$; group GrA) compared with calves not supplemented with arginine (group $\mathrm{GrC}$ ). Arginine supplementation alone caused a significant rise of plasma arginine, urea, and insulin concentrations, whereas glucagon concentrations tended to increase, but there were no significant group differences. Concentrations of triglycerides, NEFA, glucose, protein, albumin, growth hormone, insulin-like growth factor-I, 3.5.3'-triiodothyronine, and thyroxine were not affected by arginine supplementation. Lipopolysaccharide administration alone caused a rise of tumor necrosis-factor- $\alpha$, lactate, and cortisol concentrations and concentrations of tumor necrosis-factor- $\alpha$ after $1 \mathrm{~h}$, and of triglycerides and urea after $6 \mathrm{~h}$ were higher, whereas of glucose after $3 \mathrm{~h}$ were lower in GrA than in GrC. Concentrations of NEFA, glucose, protein, albumin, insulin, growth hormone, insulin-like growth factor-I, 3.5.3'-triiodothyronine, and thyroxine were not affected by lipopolysaccharide administration. In conclusion, arginine supplementation had selective effects on plasma metabolites and hormones, but barely modified lipopolysaccharide effects. Effects of lipopolysaccharides in the postprandial state were different from what is usually seen in the fasted state.
\end{abstract}

(Key words: veal calf, arginine, endotoxin, metabolite)

Abbreviation key: $\mathbf{G H}=$ growth hormone, GrA = group supplemented with arginine, $\mathbf{G r C}=$ control group, LPS = lipopolysaccharides, NO = nitric oxide,

Received November 26, 2001.

Accepted February 19, 2002.

Corresponding author: J. W. Blum; e-mail: blum@itz.unibe.ch.

${ }^{1}$ Part of a thesis of B. R. H. for Dr. med. vet., accepted 1999 by the Veterinary Faculty, University of Berne, Switzerland. Present address: CH-5043 Holziken, Switzerland.
$\mathbf{T G}=$ triglycerides, $\mathbf{T N F}-\alpha=$ tumor necrosis factor $-\alpha$, $\mathbf{T}_{3}=$ 3.5.3'-triiodothyronine; $\mathbf{T}_{\mathbf{4}}=$ thyroxine.

\section{INTRODUCTION}

The amino acid L-Arg is essential for optimal growth of young and especially for premature and neonatal animals of several species (Visek, 1986; Guilhermet, 1996; Kirchgesssner, 1997; Wu et al., 2000). However, Arg provided with whole milk may not fully meet requirements for some species (Reeds and Hutchens, 1994; Wu et al., 2000). Although Arg content in milk is considered sufficient for maintenance (Toullec, 1988), it can be insufficient for maximal growth in milk-fed, preruminant calves (Williams and Hewitt, 1979; Fligger et al., 1997), particularly if they are fed whey-based diets (Toullec, 1988). The supplementation of Arg may or may not stimulate growth performance of veal calves (Guilhermet, 1996; Fligger et al., 1997).

Arginine is known to be essential for the functioning of the urea cycle and thus for the elimination of ammonia (Barbul, 1986; Guilhermet, 1996; Eremin, 1997). It is metabolized to other AA, is a precursor of polyamines (essential substrates for cell division), and serves as a substrate for nitric oxide (NO) formation (Guilhermet, 1996; Wu et al., 2000). Arginine can enhance nitrogen retention (Guilhermet, 1996), an effect that is either direct or may be mediated by changed secretion of hormones. Parenteral administration of Arg in supraphysiological amounts stimulates the secretion of insulin (Barbul, 1986; Sano et al., 1995), glucagon (Sugano et al., 1982; Sano et al., 1995), growth hormone (GH) (Chew et al., 1984; Barbul, 1986) and prolactin (Chew et al., 1984), and the intraduodenal infusion of Arg to pigs stimulated the secretion of GH and insulin (Cochard et al., 1998).

Infection-induced immunological stress and exposure to bacterial toxins, such as endotoxins (lipopolysaccharides, LPS), modify nutrient requirements and thus growth performance (Klasing, 1988; Elsasser et al., 1995, 2000). Gram-negative bacterial infections, especially with Escherichia coli, are frequent in calves (Fey, 1976; Acres, 1985). During gram-negative infections calves are exposed to increased amounts of LPS, which 
cause serious cardio-respiratory, hematological, metabolic and endocrine changes, evoked by cytokines, such as tumor necrosis factor- $\alpha$ (TNF- $\alpha$; Kenison et al., 1991; Kinsbergen et al., 1994; Elsasser, 1995, 2000). The administration of LPS to heifers was shown to stimulate the production of bactericidal NO, an effect that was enhanced by i.v. administered Arg (Kahl et al., 1997). The Arg supplementation enhances immune reactions (Guilhermet, 1996; Eremin, 1997; Efron and Barbul, 1998; Wu et al., 2000) and positive effects can be expected if Arg is prophylactically provided in situations in which enhanced immune reactions, including NO formation, are required. Thus, during infections, Arg may become conditionally essential for host defense and survival (Kirk and Barbul, 1990; Eremin, 1997; Wu et al., 2000). It is realized, however, that a too high Arg supplementation may not only cause AA imbalances, especially with lysine (Kirchgesssner, 1997), but may additionally led to exaggerated NO production, oxidative stress, and nitrosylation of proteins (Elsasser et al., 2000). This would expectedly disturb homeostatic endocrine control of metabolism, enhance morbidity and mortality rates, and reduce performance, such as growth rates. Therefore, an optimal Arg supplementation and status is important.

Reports on endocrine and metabolic changes of combined oral Arg and parenteral LPS administration in veal calves are, to our knowledge, lacking. Furthermore, such studies on LPS effects have to our knowledge been performed only in fasted calves (Kenison et al., 1991; Kinsbergen et al., 1994). The purpose of this study was therefore to characterize blood TNF- $\alpha$, hormone, and metabolite responses to Arg in calves provided normal feed and with or without intravenously administered LPS. The hypothesis was tested that LPS administration differently modifies postprandial metabolic and endocrine changes if combined or if not combined with Arg supplementation.

\section{MATERIALS AND METHODS}

\section{Animals and Husbandry}

Experimental protocols followed the Swiss law of animal protection and were approved by the Committee for the Permission of Animal Experiments of the Canton of Freiburg, Granges-Paccot, Switzerland.

Twelve male veal calves (Simmental $\times$ Red Holstein) were bought at the age of 5 or $6 \mathrm{wk}$ and housed at the Research Station in Posieux, Switzerland. On arrival, calves were ear-tagged and given a 5 -d prophylactic antibiotic treatment (Viro Sultrim M, Veterinaria AG, Zürich, Switzerland). Calves were weighed and examined weekly. They were kept in loose housing systems on straw litter and fed by bucket whole milk without supplements twice daily (at 0800 and at $1600 \mathrm{~h}$ ) in amounts of $100-150 \mathrm{~g} / \mathrm{kg}$ of BW. Ambient temperatures were between 15 and $20^{\circ} \mathrm{C}$.

\section{Experimental Procedures}

The experiments started at the age of $8 \mathrm{wk}$, i.e., at a BW of $90 \pm 1.3 \mathrm{~kg}$. Two groups were created, each consisting of six calves. During the experimental period, lasting for $5 \mathrm{~d}$, group A (GrA) was supplemented with Arg $(0.25 \mathrm{~g} / \mathrm{kg}$ of BW per meal) for $4 \mathrm{~d}$ (d 1 to $\mathrm{d} 4)$ with milk twice daily (at 0800 and $1600 \mathrm{~h}$ ), whereas group C (GrC) served as control and received no Arg supplementation. According to the feeding plan, the daily feed intake throughout the experimental period was constant. Because calves did not like the taste and smell of Arg, we added $0.5 \mathrm{~g}$ of a mixture consisting of sweeteners (1/3 neohespiridin-dihydrochalcon and 1/3 saccharine, UFA AG, Sursee, Switzerland) and of an aromatic substance (1/3 Bigarol, Harmann and Reimer, Holzminden, Germany) per kg of milk to calves of GrA. The same amounts of the sweeteners were also added to the milk of calves of GrC. Food intake could thus be kept nearly identical in the two groups. It was expected that the very small amounts of these sweeteners do not have effects on metabolism and hormones, such as on insulin levels. On d 1 of the experiment, calves were moved into wooden boxes (100 cm wide, $150 \mathrm{~cm}$ long). On d 4, LPS (endotoxin of Escherichia coli O26:B6; Sigma Chemical Co, St. Louis, MO; $2 \mu \mathrm{g} / \mathrm{kg}$ of BW) was i.v. injected during the morning meal.

Blood samples $(20 \mathrm{ml})$ were taken on $\mathrm{d} 1$ and 5 of the experiment from jugular veins with evacuated tubes before the morning meal. On d 2, catheters were inserted into a jugular vein and fixed by surgical suture and adhesive band. On $\mathrm{d} 3$ and 4 blood samples (10 ml) were collected before and every $30 \mathrm{~min}$ up to $6 \mathrm{~h}$ after the morning meal.

Concentrations of albumin, total protein, urea, 3.5.3'triiodotyronine $\left(\mathbf{T}_{3}\right)$, thyroxine $\left(\mathbf{T}_{4}\right)$, and IGF-I were determined on $\mathrm{d} 1$ and 5 before feeding and on $\mathrm{d} 3$ and 4 before and at $6 \mathrm{~h}$ after feeding. Glucose, l-lactate, NEFA, triglycerides (TG), insulin, and glucagon concentrations were determined in preprandial blood samples on $\mathrm{d} 1,3,4$, and 5 , and in hourly postprandial samples until $6 \mathrm{~h}$ after the morning meal on $\mathrm{d} 3$ and 4. On d 3 and 4 blood was collected before and every 30 min up to $6 \mathrm{~h}$ after the morning meal for study of secretory profiles of cortisol and GH. Concentrations of Arg were measured preprandially on d 1,3 , and 4 and on $\mathrm{d} 3$ and 4 at 2,4 , and $6 \mathrm{~h}$ postprandially. Concentrations of TNF- $\alpha$ were measured pre- and postprandially, but only on $d 4$. 
Tubes containing dipotassium-EDTA ( $1.8 \mathrm{~g} / \mathrm{L}$ blood) were used to collect blood for the determination of Arg, protein, albumin, urea, glucose, NEFA, TG, TNF- $\alpha, \mathrm{T}_{3}$, $\mathrm{T}_{4}$, IGF-I, insulin, and glucagon in plasma. To determine plasma lactate, we used tubes containing $1.8 \mathrm{~g}$ of dipotassium-EDTA and $3 \mathrm{~g}$ of sodium-fluoride/L of blood. After collection tubes were cooled on ice and centrifuged within $1 \mathrm{~h}$ after collection at $1000 \times g$ for 20 min at $4^{\circ} \mathrm{C}$, then the supernatants were portioned into aliquots and stored at $-20^{\circ} \mathrm{C}$ until analyzed.

\section{Laboratory Analyses}

Urea, glucose, TG, and protein concentrations were measured using kits (\# 073685 6, 073671 6, 073679 1, and 073678 3, respectively) from F. Hoffmann-La Roche (Basle, Switzerland), whereas kits (\# 61051 and 61192, respectively) from Bio Mérieux (Marcy l'Etoile, France) were used to determine albumin and lactate, and the concentration of NEFA was measured with a kit (\#994-75409) from Wako (Neuss, Germany) using an automatic analyzer "Cobas Mira Plus," F. HoffmannLa-Roche (Basel, Switzerland). Concentrations of Arg were measured (before and at 2,4 , and $6 \mathrm{~h}$ after feeding) at the Institute of Chemistry and Biochemistry (University of Berne, Berne, Switzerland) as described (Hammon and Blum, 1999). In short, plasma samples were deproteinized with acetonitril ( $800 \mathrm{~g} / \mathrm{l} ; 1 \mathrm{ml}$ of acetonitril per $1 \mathrm{ml}$ of serum), dried during centrifugation under vacuum and frozen until Arg (besides other AA) was (were) measured following precolumn derivatization by HPLC. Norleucine (200 pmol per injection) was used as internal standard and was added before protein precipitation.

The concentrations of TNF- $\alpha$ (Kinsbergen et al., 1994; Kahl et al., 1997) and insulin, glucagon, IGF-I, $\mathrm{T}_{3}, \mathrm{~T}_{4}$, $\mathrm{GH}$, as well as cortisol were measured by radioimmunoassay (Kaufhold et al., 2000).

\section{Statistical Analyses}

Values of metabolites and hormones are expressed as means \pm SEM. Mean concentrations, basal concentrations, amplitudes of peaks, and peak frequencies of GH on d 3 and 4 were analyzed according to Merriam and Wachter (1982). For time and treatment differences, preprandial values on $\mathrm{d} 1,3,4$, and 5 of the experiment, and postprandial effects and episodic secretion on $\mathrm{d} 3$ and 4 of the experiments were evaluated by separate mixed procedures using the repeated measure analysis (SAS Institute, 1994). The model included the evaluation of effects of time, treatments (Arg supplementation or LPS administration) and interactions between Arg supplementation and LPS administration.
The time-dependent differences within groups and differences of treatment effects between groups were considered significant if $P<0.05$.

\section{RESULTS}

\section{Plasma Metabolite Concentrations}

Preprandial Arg concentrations were similar in both groups (means \pm SEM: $118 \pm 5$ and $112 \pm 10 \mu \mathrm{mol} / \mathrm{L}$ in GrC and GrA, respectively; $P>0.1$ ). In GrC, the Arg concentrations did not change postprandially and after endotoxin administration, whereas in GrA plasma Arg concentrations postprandially increased $(P<0.01)$ similarly on d 3 and on d 4 (to $180 \pm 18,220 \pm 25$ and 205 $\pm 26 \mu \mathrm{mol} / \mathrm{L}$ at 2,4 and $6 \mathrm{~h}$ after feeding, respectively).

Preprandial protein concentrations (Table 1) were lower $(P<0.05)$ on $\mathrm{d} 4$ than on $\mathrm{d} 1$ and 5 in $\mathrm{GrC}$, and were lower $(P<0.01)$ on $\mathrm{d} 3,4$, and 5 than on $\mathrm{d} 1$ in GrA, and on d 3 and d 4 decreased $(P<0.05)$ at $6 \mathrm{~h}$ after feeding in both groups. There were no significant group differences $(P>0.1)$.

Preprandial albumin concentrations (Table 1) in GrC were lower $(P<0.05)$ on 4 than on $\mathrm{d} 1$ and 5 and in GrA were lower on $\mathrm{d} 3,4$, and 5 than on $\mathrm{d} 1$. Concentrations decreased $(P<0.01)$ at $6 \mathrm{~h}$ after feeding in both groups on d 3, and on d 4 in GrA. There were no significant group differences $(P>0.1)$.

Preprandial urea concentrations (Table 1) in GrA on $\mathrm{d} 3,4$, and 5 were higher $(P<0.01)$ than on $\mathrm{d} 1$. Preprandial concentrations on $\mathrm{d} 3,4$, and 5 , and concentrations at $6 \mathrm{~h}$ after feeding on $\mathrm{d} 3$ and 4 in GrA were higher $(P<0.01)$ than in $\mathrm{GrC}$.

Preprandial glucose concentrations (Figure 1) in GrC were lower $(P<0.05)$ on $\mathrm{d} 4$ than on $\mathrm{d} 5$, and on $\mathrm{d}$ 1 and 3 were lower $(P<0.05)$ in GrA than in GrC. Concentrations increased $(P<0.05)$ in $\mathrm{GrA}$ and $\mathrm{GrC}$ on $\mathrm{d} 3$ and 4 at 1 and $2 \mathrm{~h}$ and (in part at $3 \mathrm{~h}$ ) after feed intake. On $\mathrm{d} 4$ at $3 \mathrm{~h}$ after feed intake, the postprandial rise was smaller $(P<0.05)$ in GrA than in GrC.

Preprandial lactate concentrations (Figure 2) in GrA on $d 1$ were higher $(P<0.05)$ than on $d 3,4$, and 5 . On d 3 there was a slow postprandial increase $(P<0.05)$ of concentrations at $1,2,3$, and $4 \mathrm{~h}$ in GrA, whereas on $\mathrm{d} 4$ at $1,2,3$, and $4 \mathrm{~h}$ concentrations increased $(P<$ 0.01) markedly in GrA and GrC after the LPS injections. There were no significant group differences $(P>0.1)$.

Concentrations of NEFA on d 3 and 4 (Figure 3 ) in both groups decreased $(P<0.05)$ at $1,2,3,4$, and $5 \mathrm{~h}$ and (in part at $6 \mathrm{~h}$ ) after feeding with and without LPS administration. There were no group differences $(P>$ $0.1)$, except for higher $(P<0.05)$ preprandial concentrations in GrC than GrA on d 4.

Preprandial triglyceride concentrations (Figure 4) in GrC on $\mathrm{d} 3,4$, and 5 were higher $(P<0.05)$ than on $\mathrm{d}$ 
Table 1. Blood plasma concentrations of total protein, albumin, and urea ${ }^{1}$

\begin{tabular}{|c|c|c|c|c|c|c|c|}
\hline Trait & Group & $\begin{array}{c}\text { Day } 1 \\
\text { Preprandial }\end{array}$ & $\begin{array}{c}\text { Day } 3 \\
\text { Preprandial }\end{array}$ & $6 \mathrm{~h}$ & $\begin{array}{c}\text { Day } 4 \\
\text { Preprandial }\end{array}$ & $6 \mathrm{~h}$ & $\begin{array}{c}\text { Day } 5 \\
\text { Preprandial }\end{array}$ \\
\hline $\begin{array}{l}\text { Protein } \\
(\mathrm{g} / \mathrm{L})\end{array}$ & $\begin{array}{l}\mathrm{GrC} \\
\mathrm{GrA}\end{array}$ & $\begin{array}{l}51.8 \pm 0.9^{\mathrm{a}} \\
54.5 \pm 1.7^{\mathrm{a}}\end{array}$ & $\begin{array}{l}50.2 \pm 0.8^{\mathrm{ab}} \\
51.1 \pm 1.4^{\mathrm{b}}\end{array}$ & $\begin{array}{l}46.1 \pm 0.9^{*} \\
46.8 \pm 1.3^{*}\end{array}$ & $\begin{array}{l}49.6 \pm 1.0^{\mathrm{b}} \\
49.5 \pm 0.7^{\mathrm{b}}\end{array}$ & $\begin{array}{l}47.6 \pm 0.7^{*} \\
46.8 \pm 1.3^{*}\end{array}$ & $\begin{array}{l}51.4 \pm 1.6^{\mathrm{a}} \\
50.8 \pm 1.2^{\mathrm{b}}\end{array}$ \\
\hline $\begin{array}{l}\text { Albumin } \\
(\mathrm{g} / \mathrm{L})\end{array}$ & $\begin{array}{l}\mathrm{GrC} \\
\mathrm{GrA}\end{array}$ & $\begin{array}{l}38.0 \pm 0.4^{\mathrm{a}} \\
38.9 \pm 0.9^{\mathrm{a}}\end{array}$ & $\begin{array}{l}37.3 \pm 0.4^{\mathrm{ab}} \\
37.2 \pm 1.0^{\mathrm{b}}\end{array}$ & $\begin{array}{l}34.8 \pm 0.7^{*} \\
33.9 \pm 0.9^{*}\end{array}$ & $\begin{array}{l}36.3 \pm 0.7^{\mathrm{b}} \\
36.0 \pm 0.9^{\mathrm{c}}\end{array}$ & $\begin{array}{l}35.2 \pm 0.3 \\
34.3 \pm 0.5^{*}\end{array}$ & $\begin{array}{l}37.6 \pm 0.7^{\mathrm{a}} \\
36.7 \pm 1.0^{\mathrm{bc}}\end{array}$ \\
\hline $\begin{array}{l}\text { Urea } \\
(\mathrm{mmol} / \mathrm{L})\end{array}$ & $\begin{array}{l}\mathrm{GrC} \\
\mathrm{GrA}\end{array}$ & $\begin{array}{l}2.3 \pm 0.2^{\mathrm{ab}} \\
2.9 \pm 0.2^{\mathrm{c}}\end{array}$ & $\begin{array}{l}2.5 \pm 0.2^{\mathrm{Bab}} \\
4.3 \pm 0.2^{\mathrm{Aa}}\end{array}$ & $\begin{array}{l}2.5 \pm 0.3^{\mathrm{B}} \\
4.3 \pm 0.3^{\mathrm{A}}\end{array}$ & $\begin{array}{l}2.4 \pm 0.2^{\mathrm{Bb}} \\
3.7 \pm 0.2^{\mathrm{Ab}}\end{array}$ & $\begin{array}{l}2.5 \pm 0.3^{\mathrm{B}} \\
3.5 \pm 0.3^{\mathrm{A}}\end{array}$ & $\begin{array}{l}3.0 \pm 0.5^{\mathrm{Ba}} \\
3.9 \pm 0.2^{\mathrm{Ab}}\end{array}$ \\
\hline
\end{tabular}

a,b,c Means of preprandial values with different small superscript letters are significantly different $(P<$ 0.05 ) within GrC and GrA.

${ }^{\mathrm{A}, \mathrm{B}}$ Means with different capital superscript letters are significantly different $(P<0.05)$ between groups.

${ }^{1}$ Values are means $\pm \mathrm{SEM}, \mathrm{N}=6$ per group. Calves were studied during $5 \mathrm{~d}$ at the age of 8 wk. Calves were fed milk with or without Arg supplementation. The Arg supplementation $(0.5 \mathrm{~g} / \mathrm{kg}$ of BW per day for $4 \mathrm{~d}$ ) started on d 1 of the experimental week. Lipopolysaccharides (endotoxin of Escherichia coli O26:B6; 2 $\mu \mathrm{g} / \mathrm{kg}$ of BW) were intravenously injected on $\mathrm{d} 4$ during the morning meal.

* Means at $6 \mathrm{~h}$ after feeding are significantly different $(P<0.05)$ from prefeeding values on $\mathrm{d} 3$ and 4 within $\mathrm{GrC}$ or $\mathrm{GrA}$.

1 , and in GrA on $d 1$ were higher $(P<0.05)$ than on $d$ 3 and 4. On d 3, concentrations in GrC decreased $(P<$ 0.05 ) at $2,3,4$, and $5 \mathrm{~h}$, and in GrA at $3 \mathrm{~h}$ after feeding. On $\mathrm{d} 4$ at 2,3 , and $5 \mathrm{~h}$ after the LPS administration and feeding concentrations decreased $(P<0.05)$ in $\mathrm{GrC}$, but not significantly in $\mathrm{GrA}$, and concentrations after $6 \mathrm{~h}$ were higher $(P<0.05)$ in $\mathrm{GrA}$ than $\mathrm{GrC}$.

\section{Plasma TNF- $\alpha$ and Hormone Concentrations}

Concentrations of TNF- $\alpha$ (measured only on $\mathrm{d} 4$ ) in $\mathrm{GrC}$ increased $(P<0.05)$ from $15 \pm 4 \mathrm{ng} / \mathrm{L}$ at 0800 to

Day 1

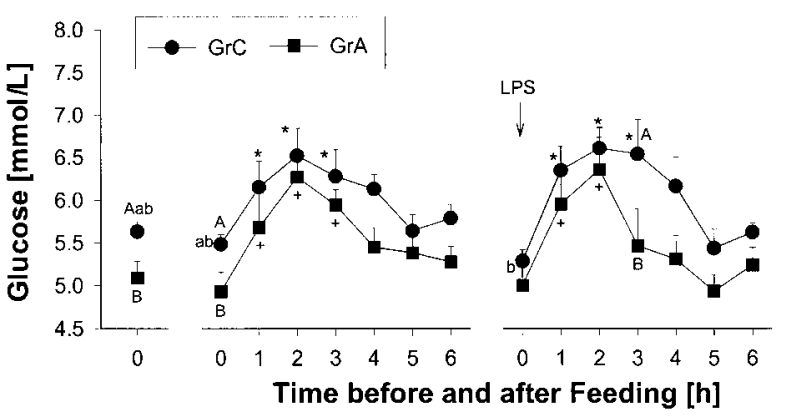

Figure 1. Pre- and postprandial plasma glucose concentrations of calves without supplementation ( $\mathrm{GrC}$ ) or with Arg supplementation (GrA). Values are means $\pm \mathrm{SEM}, \mathrm{n}=6$ per group. The Arg supplementation $(0.5 \mathrm{~g} / \mathrm{kg}$ of BW per day for $4 \mathrm{~d})$ started on $\mathrm{d} 1$ of the experimental week. The LPS (endotoxin of Escherichia coli O26:B6; $2 \mu \mathrm{g} / \mathrm{kg}$ of $\mathrm{BW}$ ) was intravenously injected on $\mathrm{d} 4$ during the morning meal. Means with different capital superscript letters (A, B) are significantly different $(P<0.05)$ between groups; means with the different small superscript letters $(\mathrm{a}, \mathrm{b}, \mathrm{c})$ are significantly different $(P<0.05)$ within $\mathrm{GrC}$ and means with the different small superscript letters $(\mathrm{d}, \mathrm{e}, \mathrm{f})$ in GrA. * means are significantly different $(P<0.05)$ from prefeeding values within $\mathrm{GrC} ;+$ means are significantly different $(P$ $<0.05$ ) from prefeeding values within GrA.
$58 \pm 18 \mathrm{ng} / \mathrm{L}$ after $1 \mathrm{~h}$, and then decreased to $23 \pm 8$, $12 \pm 5,18 \pm 3$, and $15 \pm 6 \mathrm{ng} / \mathrm{L}$ after $2,3,4$, and $6 \mathrm{~h}$, respectively. Concentrations in GrA on $\mathrm{d} 4$ increased $(P<0.05)$ from $15 \pm 4 \mathrm{ng} / \mathrm{L}$ at $0800 \mathrm{~h}$ to $68 \pm 9 \mathrm{ng} / \mathrm{L}$ after $1 \mathrm{~h}$, and then decreased to $18 \pm 3,17 \pm 5,17 \pm 2$, and $12 \pm 5 \mathrm{ng} / \mathrm{L}$ after $2,3,4$, and $6 \mathrm{~h}$, respectively. Concentrations at $1 \mathrm{~h}$ after LPS administrations in GrA were higher $(P<0.05)$ than in $\mathrm{GrC}$.

Preprandial concentrations of insulin on $\mathrm{d} 1,3$, and 5 were similar. Concentrations (Figure 5 ) on d 3 increased $(P<0.05)$ after feeding in GrA, but not significantly in GrC. On d 4, concentrations increased $(P<$ 0.05 ) in $\mathrm{GrC}$ after feeding plus LPS administration, but

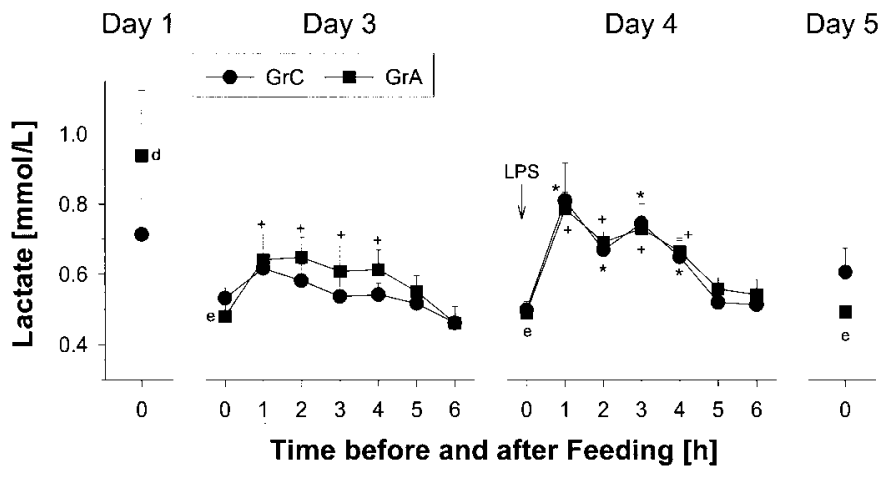

Figure 2. Pre- and postprandial plasma lactate concentrations in GrA and GrC. Values are means \pm SEM, $\mathrm{n}=6$ per group. The Arg supplementation $(0.5 \mathrm{~g} / \mathrm{kg}$ of BW per day for $4 \mathrm{~d})$ started on $\mathrm{d} 1$ of the experimental week. The LPS (endotoxin of Escherichia coli O26:B6; 2 $\mu \mathrm{g} / \mathrm{kg}$ of BW) was intravenously injected on $\mathrm{d} 4$ during the morning meal. Means with different capital superscript letters (A, B) are significantly different $(P<0.05)$ between groups; means with the different small superscript letters $(a, b, c)$ are significantly different $(P<$ 0.05 ) within $\mathrm{GrC}$ and means with the different small superscript letters $(\mathrm{d}, \mathrm{e}, \mathrm{f})$ in $\mathrm{GrA}$. * means are significantly different $(P<0.05)$ from prefeeding values within $\mathrm{GrC}$; + means are significantly different $(P<0.05)$ from prefeeding values within $\mathrm{GrA}$. 


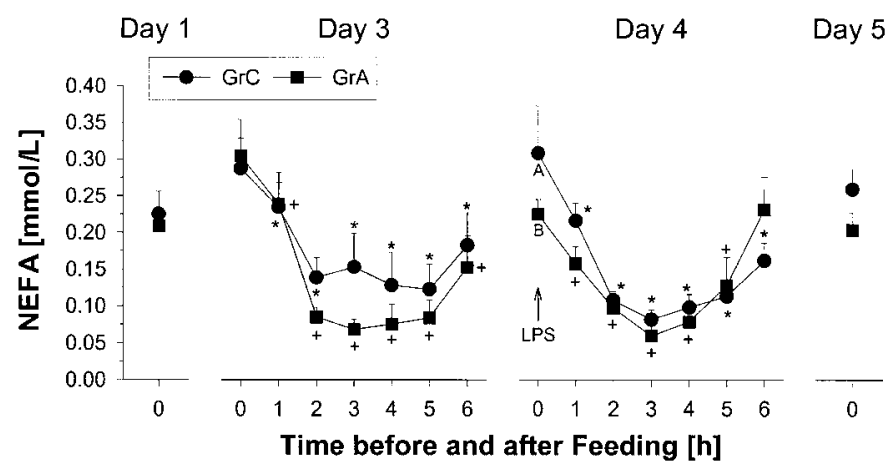

Figure 3. Pre- and postprandial plasma NEFA concentrations in GrA and GrC. Values are means \pm SEM, $\mathrm{n}=6$ per group. The Arg supplementation $(0.5 \mathrm{~g} / \mathrm{kg}$ of BW per day for $4 \mathrm{~d})$ started on $\mathrm{d} 1$ of the experimental week. The LPS (endotoxin of Escherichia coli O26:B6; 2 $\mu \mathrm{g} / \mathrm{kg}$ of BW) was intravenously injected on d 4 during the morning meal. Means with different capital superscript letters (A, B) are significantly different $(P<0.05)$ between groups; means with the different small superscript letters $(\mathrm{a}, \mathrm{b}, \mathrm{c})$ are significantly different $(P<$ 0.05 ) within $\mathrm{GrC}$ and means with the different small superscript letters $(\mathrm{d}, \mathrm{e}, \mathrm{f})$ in $\mathrm{GrA} . *$ means are significantly different $(P<0.05)$ from prefeeding values within $\mathrm{GrC}$; + means are significantly different $(P<0.05)$ from prefeeding values within GrA.

only tended to rise $(P<0.1)$ in GrA after feeding plus LPS administration (although concentrations were in a similar range as on $d 3$ ). On $d 3$, concentrations in GrA at $2 \mathrm{~h}$ after feeding were higher $(P<0.05)$ than in $\mathrm{GrC}$, but on d 4 were similar in both groups.

Preprandial concentrations of glucagon (Figure 6) in GrC were higher $(P<0.05)$ on $d 5$ than on $d 1$. Concen-

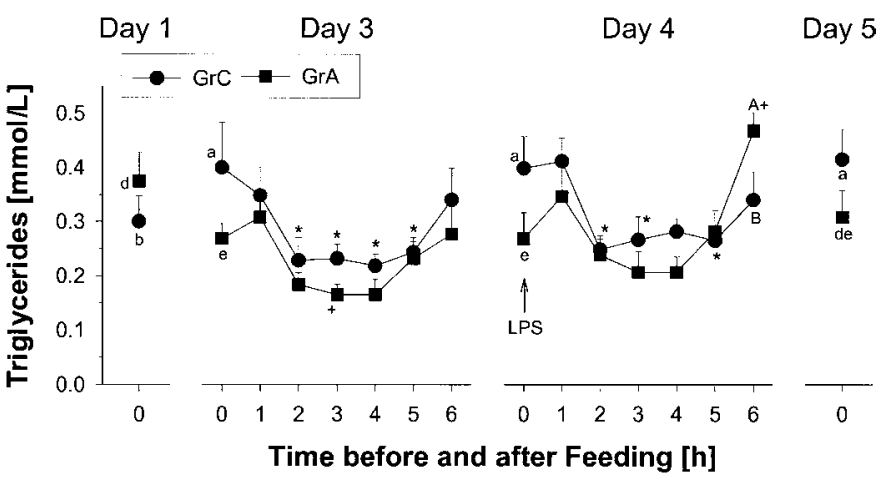

Figure 4. Pre- and postprandial plasma triglyceride concentrations in GrA and GrC. Values are means \pm SEM, $\mathrm{n}=6$ per group. The Arg supplementation ( $0.5 \mathrm{~g} / \mathrm{kg}$ of BW per day for $4 \mathrm{~d})$ started on d 1 of the experimental week. The LPS (endotoxin of Escherichia coli O26:B6; $2 \mu \mathrm{g} / \mathrm{kg}$ of BW) was intravenously injected on d 4 during the morning meal. Means with different capital superscript letters (A, B) are significantly different $(P<0.05)$ between groups; means with the different small superscript letters $(\mathrm{a}, \mathrm{b}, \mathrm{c})$ are significantly different $(P<0.05)$ within $\mathrm{GrC}$ and means with the different small superscript letters (d, e, f) in GrA. * means are significantly different $(P$ $<0.05$ ) from prefeeding values within $\mathrm{GrC}$; + means are significantly different $(P<0.05)$ from prefeeding values within GrA.

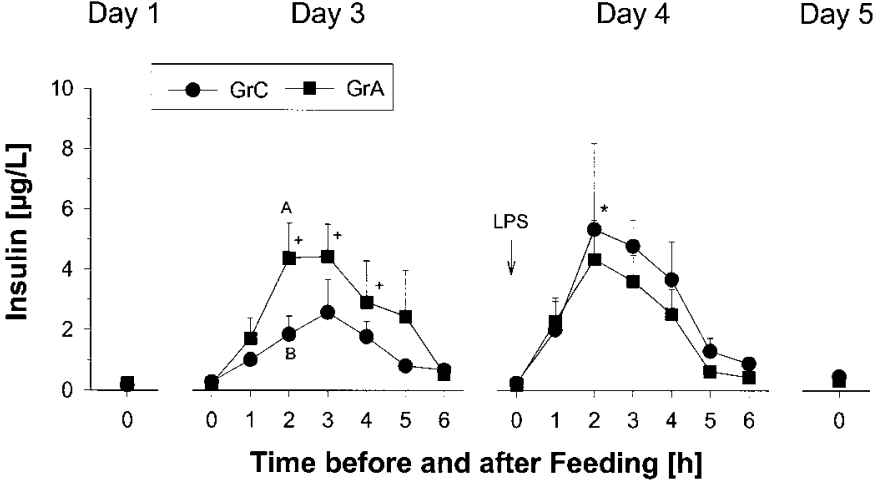

Figure 5. Pre- and postprandial plasma insulin concentrations in GrA and GrC. Values are means \pm SEM, $\mathrm{n}=6$ per group. The Arg supplementation $(0.5 \mathrm{~g} / \mathrm{kg}$ of BW per day for $4 \mathrm{~d})$ started on $\mathrm{d} 1$ of the experimental week. The LPS (endotoxin of Escherichia coli O26:B6; 2 $\mu \mathrm{g} / \mathrm{kg}$ of BW) was intravenously injected on $\mathrm{d} 4$ during the morning meal. Means with different capital superscript letters (A, B) are significantly different $(P<0.05)$ between groups; means with the different small superscript letters (a, b, c) are significantly different $(P<$ 0.05 ) within $\mathrm{GrC}$ and means with the different small superscript letters $(\mathrm{d}, \mathrm{e}, \mathrm{f})$ in $\mathrm{GrA} . *$ means are significantly different $(P<0.05)$ from prefeeding values within $\mathrm{GrC}$; + means are significantly different $(P<0.05)$ from prefeeding values within GrA.

trations on $\mathrm{d} 3$ at 3 and $4 \mathrm{~h}$ increased $(P<0.05)$ in GrA after feeding, and on $\mathrm{d} 4$ at 1,2 , and $3 \mathrm{~h}$ after feeding, whereas in GrC there was only a postprandial increase $(P<0.05)$ on $\mathrm{d} 4$ at $2 \mathrm{~h}$ after feeding. There were no significant group differences $(P>0.1)$.

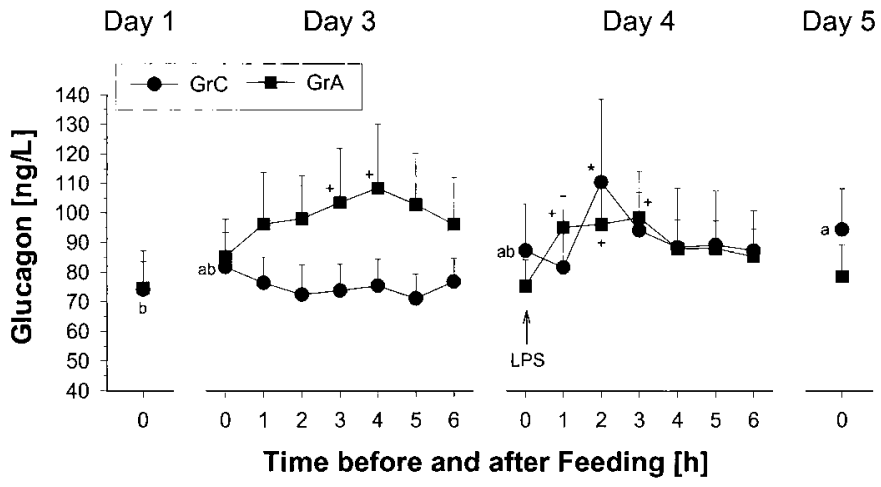

Figure 6. Pre- and postprandial plasma glucagon concentrations in $\mathrm{GrA}$ and $\mathrm{GrC}$. Values are means $\pm \mathrm{SEM}, \mathrm{n}=6$ per group. The Arg supplementation $(0.5 \mathrm{~g} / \mathrm{kg}$ of BW per day for $4 \mathrm{~d})$ started on $\mathrm{d} 1$ of the experimental week. The LPS (endotoxin of Escherichia coli O26:B6; 2 $\mu \mathrm{g} / \mathrm{kg}$ of BW) was intravenously injected on d 4 during the morning meal. Means with different capital superscript letters (A, B) are significantly different $(P<0.05)$ between groups; means with the different small superscript letters $(\mathrm{a}, \mathrm{b}, \mathrm{c})$ are significantly different $(P<$ 0.05 ) within $\mathrm{GrC}$ and means with the different small superscript letters $(\mathrm{d}, \mathrm{e}, \mathrm{f})$ in GrA. * means are significantly different $(P<0.05)$ from prefeeding values within $\mathrm{GrC}$; + means are significantly different $(P<0.05)$ from prefeeding values within GrA. 
Table 2. Blood plasma secretory patterns of growth hormone ${ }^{1}$

\begin{tabular}{llcc}
\hline Traits & Group & Day 3 & Day 4 \\
\hline Mean $(\mu \mathrm{g} / \mathrm{L})$ & GrC & $14.2 \pm 1.2$ & $14.7 \pm 2.3$ \\
& GrA & $13.1 \pm 2.5$ & $19.1 \pm 4.2$ \\
Basal $(\mu \mathrm{g} / \mathrm{L})$ & GrC & $6.6 \pm 1.0$ & $10.4 \pm 1.8$ \\
& GrA & $3.5 \pm 0.3^{\mathrm{b}}$ & $9.6 \pm 2.1^{\mathrm{a}}$ \\
Peak Height $(\mu \mathrm{g} / \mathrm{L})$ & GrC & $29.1 \pm 5.6$ & $21.6 \pm 5.9$ \\
& GrA & $33.2 \pm 10.8$ & $39.9 \pm 18.0$ \\
Peak Frequency $\left(\mathrm{h}^{-1}\right)$ & GrC & $0.31 \pm 0.03$ & $0.33 \pm 0.07$ \\
& GrA & $0.42 \pm 0.04$ & $0.36 \pm 0.07$ \\
\hline
\end{tabular}

\footnotetext{
${ }^{a, b}$ Means with different small superscript letters are significantly different $(P<0.05)$ between days within $\mathrm{GrC}$ and $\mathrm{GrA}$. There were no significant group differences $(P>0.1)$.

${ }^{1}$ Values are means \pm SEM, $N=6$ per group. Calves were studied during $5 \mathrm{~d}$ at the age of $8 \mathrm{wk}$. Calves were fed milk with or without Arg supplementation. The Arg supplementation $(0.5 \mathrm{~g} / \mathrm{kg}$ of BW per day for $4 \mathrm{~d}$ ) started on d 1 of the experimental week. Lipopolysaccarides (endotoxin of Escherichia coli $026: \mathrm{B} 6,2 \mathrm{mg} / \mathrm{kg}$ of BW) were intravenously injected on $\mathrm{d} 4$ during the morning meal.
}

Mean concentrations, peak heights, and peak frequencies of GH (Table 2) were similar in both groups, but in GrA, basal concentrations were higher $(P<0.05)$ on $\mathrm{d} 4$ than on $\mathrm{d} 3$. Concentrations of GH and secretory patterns after feed intake did not change (not shown). There were no significant group differences $(P>0.1)$.

Preprandial cortisol concentrations (Figure 7) in GrC were higher $(P<0.05)$ on $\mathrm{d} 3$ than on $\mathrm{d} 5$. On $\mathrm{d} 3$, concentrations in $\mathrm{GrC}$ slightly decreased $(P<0.05)$ at 3 and $4 \mathrm{~h}$ after feed intake, but, on $\mathrm{d} 4$, concentrations markedly increased $(P<0.01)$ in both groups at 1 and 2

Day 1

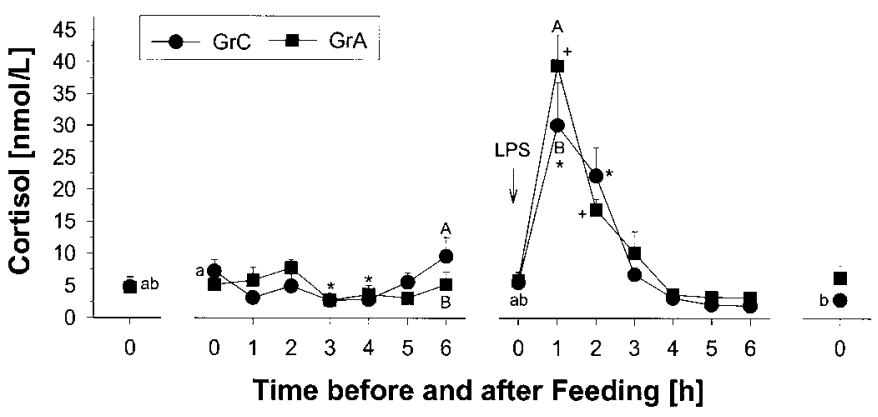

Figure 7. Pre- and postprandial plasma cortisol concentrations in $\mathrm{GrA}$ and $\mathrm{GrC}$. Values are means $\pm \mathrm{SEM}, \mathrm{n}=6$ per group. The Arg supplementation $(0.5 \mathrm{~g} / \mathrm{kg}$ of BW per day for $4 \mathrm{~d})$ started on $\mathrm{d} 1$ of the experimental week. The LPS (endotoxin of Escherichia coli O26:B6; 2 $\mu \mathrm{g} / \mathrm{kg}$ of BW) was intravenously injected on $\mathrm{d} 4$ during the morning meal. Means with different capital superscript letters (A, B) are significantly different $(P<0.05)$ between groups; means with the different small superscript letters (a, b, c) are significantly different $(P<$ 0.05 ) within $\mathrm{GrC}$ and means with the different small superscript letters $(\mathrm{d}, \mathrm{e}, \mathrm{f})$ in GrA. * means are significantly different $(P<0.05)$ from prefeeding values within $\mathrm{GrC}$; + means are significantly different $(P<0.05)$ from prefeeding values within GrA. $\mathrm{h}$ after feeding and LPS administration. Concentrations were higher $(P<0.05)$ on $\mathrm{d} 3$ at $6 \mathrm{~h}$ after feeding in GrC than in GrA, whereas on $\mathrm{d} 4$ were higher $(P<0.05)$ at $1 \mathrm{~h}$ after feeding plus LPS injection in GrA than in $\mathrm{GrC}$.

Preprandial IGF-I concentrations (Table 3) in GrA were lower $(P<0.05)$ on $\mathrm{d} 4$ than on $\mathrm{d} 1$ and 3 , but there were no significant postprandial changes and group differences $(P>0.1)$.

Preprandial $\mathrm{T}_{3}$ concentrations (Table 3 ) in $\mathrm{GrC}$ were lower $(P<0.05)$ on $\mathrm{d} 4$ and 5 than on $\mathrm{d} 1$, on $\mathrm{d} 5$ were lower $(P<0.05)$ than on $\mathrm{d} 3$, and preprandial concentrations on $\mathrm{d} 1$ and $\mathrm{d} 3$ were lower $(P<0.05)$ in GrA than in GrC.

Preprandial $\mathrm{T}_{4}$ concentrations (Table 3 ) in GrC were lower $(P<0.05)$ on $\mathrm{d} 4$ and 5 than on $\mathrm{d} 1$, but there were no significant postprandial changes and group differences $(P>0.1)$.

\section{DISCUSSION}

\section{Plasma Metabolite Concentrations}

This study was performed under conditions as planned, i.e., feed intakes in the two groups were not different and there were no significant day-to-day differences in feed intake. However, there was a marked postprandial increase of plasma Arg concentrations in Arg-supplemented calves, whereas Arg concentrations did not change in the control group. The Arg was administered in the highest amounts, which our veal calves were willing to ingest, i.e., calves refused milk intake if larger amounts of Arg were provided. The higher plasma urea concentrations in Arg supplemented calves than in controls was obviously the consequence of enhanced urea cycle activity because plasma Arg concentrations were increased, and its degradation leads to enhanced urea production.

Plasma albumin and protein concentrations were not influenced by Arg supplementation, by LPS administration alone, and by the combined Arg plus LPS administration. The slight decline of plasma albumin and protein concentrations during the experimental week and the decrease of concentrations on $\mathrm{d} 3$ and 4 at $6 \mathrm{~h}$ postprandially were small, and, because there were no group differences, the changes were not of concern with respect to the interpretation of the other traits.

The partially different preprandial plasma glucose concentrations in the two groups could not be ascribed to effects of Arg supplementation. Plasma glucose concentrations increased after feeding in both groups, which is typical for milk-fed calves (Hugi et al., 1997a; Kaufhold et al., 2000). On d 3, the postprandial rise was not different in the Arg-supplemented calves from that in controls, indicating that Arg also had no effect 
Table 3. Blood plasma concentrations of IGF-I, $\mathrm{T}_{3}$, and $\mathrm{T}_{4} \cdot{ }^{1}$

\begin{tabular}{|c|c|c|c|c|c|c|c|}
\hline Trait & Group & $\begin{array}{c}\text { Day } 1 \\
\text { Preprandial }\end{array}$ & $\begin{array}{c}\text { Day 3 } \\
\text { Preprandial }\end{array}$ & 6 h Postprandial & $\begin{array}{c}\text { Day } 4 \\
\text { Preprandial }\end{array}$ & 6 h Postprandial & $\begin{array}{c}\text { Day } 5 \\
\text { Preprandial }\end{array}$ \\
\hline $\begin{array}{l}\text { IGF-I } \\
(\mu \mathrm{g} / \mathrm{L})\end{array}$ & $\begin{array}{l}\text { Grc } \\
\text { GrA }\end{array}$ & $\begin{array}{l}245 \pm 17 \\
259 \pm 37^{\mathrm{a}}\end{array}$ & $\begin{array}{l}239 \pm 20 \\
259 \pm 38^{\mathrm{a}}\end{array}$ & $\begin{array}{l}238 \pm 15 \\
235 \pm 31\end{array}$ & $\begin{array}{l}245 \pm 23 \\
210 \pm 26_{\mathrm{b}}\end{array}$ & $\begin{array}{l}252 \pm 17 \\
222 \pm 24\end{array}$ & $\begin{array}{l}259 \pm 25 \\
251 \pm 34^{\mathrm{ab}}\end{array}$ \\
\hline $\begin{array}{l}\mathrm{T}_{4} \\
(\mathrm{nmol} / \mathrm{L})\end{array}$ & $\begin{array}{l}\mathrm{GrC} \\
\mathrm{GrA}\end{array}$ & $\begin{array}{l}97 \pm 5^{\mathrm{a}} \\
88 \pm 4\end{array}$ & $\begin{array}{l}98 \pm 6^{\mathrm{ab}} \\
88 \pm 5\end{array}$ & $\begin{array}{l}98 \pm 8 \\
93 \pm 5\end{array}$ & $\begin{array}{l}82 \pm 4^{\mathrm{b}} \\
80 \pm 4\end{array}$ & $\begin{array}{l}82 \pm 3 \\
81 \pm 6\end{array}$ & $\begin{array}{l}82 \pm 5^{b} \\
85 \pm 2\end{array}$ \\
\hline
\end{tabular}

${ }^{\mathrm{a}, \mathrm{b}, \mathrm{c}}$ Means of preprandial concentrations with different small superscript letters are significantly different $(P<0.05)$ within $\mathrm{GrC}$ and $\mathrm{GrA}$.

${ }^{\mathrm{A}, \mathrm{B}}$ Means with different capital superscript letters are significantly different $(P<0.05)$ between groups.

${ }^{1}$ Values are means \pm SEM, $\mathrm{N}=6$ per group. Calves were studied during $5 \mathrm{~d}$ at the age of $8 \mathrm{wk}$. Calves were fed milk with or without Arg supplementation. The Arg supplementation ( $0.5 \mathrm{~g} / \mathrm{kg}$ of BW per day for $4 \mathrm{~d})$ started on $\mathrm{d} 1$ of the experimental week. Lipopolysaccarides (endotoxin of Escherichia coli 026:B6, $2 \mathrm{mg} / \mathrm{kg}$ of BW) were intravenously injected on d 4 during the morning meal.

on postprandial hyperglycemia. However, Yelich and Filkins (1982) reported that Arg administration lowers plasma glucose concentration in rats, explained by increased concentrations of insulin, which stimulates tissue glucose uptake. Glucose metabolism is markedly affected by LPS, in part due to activation of the sympatho-medullary system (Hargrove et al., 1988) and in association with endocrine changes. However, a hypoglycemia after LPS administration, reported in other studies with calves (Kenison et al., 1991; Kinsbergen et al., 1994), was not seen, likely because LPS was administered immediately postprandially, i.e., shortly before plasma glucose concentration normally starts to increase. Lower plasma glucose concentrations in GrA than in $\mathrm{GrC}$ at $3 \mathrm{~h}$ after LPS challenges indicates that Arg supplementation modified LPS effects.

Reasons for relatively high preprandial plasma lactate levels at the start of the experimental period are not clear, but may have been the consequence of delayed stress effects after moving calves into individual boxes. A postprandial rise of plasma lactate concentrations has been previously described in milk-fed calves (Hugi et al., 1997b; Kaufhold et al., 2000), although in the present study the rise was only significant in the Argsupplemented calves. An increase of lactate concentrations after LPS administration in our calves is typical and has, too, been shown previously in veal calves (Kinsbergen et al., 1994). However, the Arg supplementation did not change plasma lactate responses to LPS, in contrast to glucose responses, indicating selective effects of Arg on glucose metabolism when combined with LPS.

That plasma NEFA concentrations rapidly decreased postprandially has been previously documented in veal calves (Hugi et al., 1997a; Kaufhold et al., 2000) and can be explained by enhanced insulin-stimulated fatty acid tissue uptake. In contrast to Kinsbergen et al. (1994), the LPS administration did not increase NEFA concentrations, likely because calves were studied post- prandially and because insulin still stimulated fatty acid tissue uptake under these conditions. Arg supplementation was without effect on NEFA responses to the LPS administration.

Plasma TG concentrations rapidly decreased postprandially in controls, as repeatedly shown in veal calves (Hugi et al., 1997a; Kaufhold et al., 2000). In the Arg supplemented calves, preprandial TG concentrations were reduced. Sugano et al. (1982), too, reported that plasma TG concentrations can be diminished by Arg supplementation in rats. This effect may have been due to Arg-stimulated insulin secretion and enhanced insulin-stimulated lipoprotein lipase activity and fatty acid tissue uptake. Plasma TG concentrations typically increase after LPS administration as a consequence of enhanced release of TNF- $\alpha$, which inhibits lipoprotein lipase (Beutler, 1988), although in calves the rise of plasma TG concentrations became significant only after $6 \mathrm{~h}$ (Kinsbergen et al., 1994). In both groups there was initially a decrease of TG concentrations after feeding and LPS administration in controls, whereas in the Arg supplementeted and LPS challenged calves the postprandial decrease of TG concentrations was reduced. However, TG concentrations then markedly increased in Arg supplemented calves and, at $6 \mathrm{~h}$, became higher than in controls. Thus, Arg obviously modified LPS effects on TG metabolism.

\section{Plasma TNF- $\alpha$ and Hormone Concentrations}

Plasma concentrations of TNF- $\alpha$ rapidly, but only transiently, increased after intravenous LPS administration, as shown previously in calves and heifers (Kenison et al. 1991; Kinsbergen et al., 1994; Kahl et al., 1997; Elsasser et al., 2000) and thus was responsible for many of the metabolic and endocrine differences seen on d 4 as compared with d 3. Importantly, Arg supplementation enhanced TNF- $\alpha$ responses to LPS, although the effect was small and transient. 
Intravenous, oral, or intraduodenal Arg administration can stimulate insulin release in rats and sheep (Sugano et al., 1982; Sano et al., 1995) and Arg of all AA seems to have the strongest insulinogenic effect (Barbul, 1986). In accordance, insulin concentrations increased more in Arg supplemented calves than in controls, although only at $2 \mathrm{~h}$ after feeding. On $\mathrm{d} 4$, insulin concentrations increased in both groups after LPS administration, but there were no significant group differences, and postprandial responses were not greater than in the absence of LPS. This was surprising because LPS was found to initially enhance insulin release (Cornell, 1983; Kenison et al., 1991; Kinsbergen et al., 1994). The importance of the biological variation of this pattern is not clear. Food intake in the two groups was not different, and there were no significant dayto-day differences in feed intake. Therefore, differences in feed intake were not responsible for the variations of insulin.

Plasma glucagon concentrations postprandially remained stable in controls, despite hyperglycemia, but this was in accordance with Kaufhold et al. (2000). However, concentrations increased postprandially in Arg supplemented calves in this study, as shown in rats (Sugano et al., 1982). Furthermore, glucagon concentrations increased after LPS administration in controls, as shown in rats (Cornell, 1983; Knowles et al., 1986). However, Arg supplementation did not lead to an additional rise of glucagon levels in LPS-treated calves.

Plasma GH levels in controls did not decrease significantly shortly after feed intake, in contrast to Kaufhold et al. (2000), possibly and in part because, energy and lactose intake and postprandial hyperglycemia in the present study were much smaller. In our study, as in the one of Fligger et al. (1997), there were no effects of Arg supplementation on GH secretory patterns, whereas increased plasma GH levels were found in Argsupplemented humans and pigs (Barbul, 1986; Cochard et al., 1998). One or several causes may be responsible for these differences, such as the basal Arg status, amounts of Arg administered, age of the animals, and species. Decreased plasma GH concentrations after LPS administration, described by Kenison et al. (1991) and Kinsbergen et al. (1994), were not found in our study. Postprandial metabolism, such as differences in glucose levels and utilization may have been responsible that LPS had no effect on the GH status in our calves. Because blood samples for GH determinations were obtained at 30-min intervals, comparison with our previous studies (Kaufhold et al., 2000) and those of others is difficult, especially with respect to values of peak amplitudes and peak frequencies.

Concentrations of IGF-I remained stable postprandially, as expected from previous studies in veal calves
(Hugi et al., 1997a; Kaufhold et al., 2000). The observed decrease of plasma IGF-I concentrations after LPS administration (Elsasser et al., 1995, 2000; Kinsbergen et al., 1994) in calves could not be demonstrated in this study. Furthermore, there was no recognizable influence of the Arg supplementation on plasma IGF-I concentrations in the absence or presence of LPS, although data of Swanson (1990) indicated such an effect.

Cortisol concentrations slightly and transiently decreased after feeding in controls, an effect which is irregularly seen in veal calves (Hugi et al., 1997a; Kaufhold et al., 2000). On the other hand, cortisol increased transiently in both groups after LPS administration, in agreeement with Kenison et al. (1991) and Kinsbergen et al. (1994), which was likely and in part the consequence of the release of TNF- $\alpha$ (Klasing, 1988). Supplementation of Arg variably influenced cortisol concentrations in the absence and presence of LPS, i.e., effects were thus probably of minor importance.

Concentrations of $\mathrm{T}_{3}$ were significantly $(P<0.05)$ or at least numerically lower in GrA, but this was already the case before the Arg supplementation started. The administration of LPS decreases hepatic 5'-monodeiodinase, which causes reduction of plasma $\mathrm{T}_{3}$ concentrations (Kahl et al., 2000). However, in contrast to previous studies in calves and heifers (Kinsbergen et al., 1994; Kahl et al., 2000) plasma $\mathrm{T}_{3}$ concentrations were not decreased after LPS administration in this study. Reasons for these discrepancies are not obvious, but may have been because calves were fed. Plasma $\mathrm{T}_{4}$ concentrations, too, were not influenced by LPS. Small but significant decreases of preprandial $\mathrm{T}_{3}$ and $\mathrm{T}_{4}$ levels during the experiment occurred only in the control group, suggesting that Arg may have some stabilizing influences on $\mathrm{T}_{4}$ concentrations.

\section{CONCLUSIONS}

The LPS administration had typical effects on various traits during the postprandial period measured in this study (increases of TNF- $\alpha$, cortisol, lactate concentrations). On the other hand, the typical effects on other traits (glucose, NEFA, TG, GH, IGF-I, insulin, $\mathrm{T}_{4}, \mathrm{~T}_{3}$ ), expected to be affected based on previous studies in nonfed calves, were lacking, likely because LPS effects were confounded with postprandial metabolic changes. The study also shows that Arg supplementation modified some traits (urea, insulin), influenced insulin especially during the postprandial period, and modulated some metabolic and endocrine responses to LPS administration. However, effects of Arg were small and only transient. 


\section{ACKNOWLEDGMENTS}

This study was supported by H. W. Schaumann-Stiftung, Hamburg, Germany and we thank Degussa AG, Hanau, Germany for the gift of L-arginine. We thank Ted Elsasser, USDA, ARS, Animal and Natural Recources Institute, Beltsville, MD, for providing bovine TNF- $\alpha$ and polyclonal antibody raised against bovine TNF- $\alpha$. The excellent technical assistance of C. Morel and Y. Zbinden (Division of Nutrition and Physiology, Faculty of Veterinary Medicine, University of Berne, Switzerland) is greatly acknowledged.

\section{REFERENCES}

Acres, S. D. 1985. Enterotoxigenic $E$. coli infections in newborn calves: A review. J. Dairy. Sci. 68:229-256.

Barbul, A. 1986. Arginine: Biochemistry, physiology and therapeutic implications. J. Parenter. Ent. Nutr. 10:227-238.

Beutler, B. 1988. Cachexia: A fundamental mechanism. Nutr. Rev. 46:369-373.

Chew, B., J. R. Eisenmann, and T. S. Tanaka. 1984. Arginine infusion stimulates prolactin, growth hormone, insulin and subsequent lactation in pregnant dairy cows. J. Dairy Sci. 67:2507-2518.

Cochard, A., R. Guilhermet, and M. Bonneau. 1998. Plasma growth hormone, insulin and amino acid responses to arginine with or without aspartic acid in pigs. Effect of the dose. Reprod. Nutr. Dev. 38:331-343.

Cornell, R. P. 1983. Role of the liver in endotoxin-induced hyperinsulinemia and hyperglucagonemia in rats. Hepatology 3:188-192.

Efron, D. T., and A. Barbul. 1998. Modulation of inflammation and immunity by arginine supplements. Curr. Opin. Clin. Nutr. Metab. Care 1:531-538.

Elsasser, T. H., N. C. Steele, and R. Fayer. 1995. Cytokines, stress, and growth modulation. Pages 261-290 in Cytokines in Animal Health and Disease. M. J. Myers and M. P. Murtaugh, eds. M. Dekker, Inc., New York.

Elsasser, T. H., S. Kahl, T. S. Rumsey, and J. W. Blum. 2000. Modulation of growth performance in disease: Reactive nitrogen compounds and their impact on cell proteins. Domest. Anim. Endocrinol. 19:75-84.

Eremin, O. 1997. L-Arginine: Biological Aspects and Clinical Application. Springer, New York.

Fey, H. 1976. Colibacillosis in calves. H. Huber Publishers, Berne, Switzerland.

Fligger, J. M., C. A. Gibson, L. M. Sordillo, and C. R. Baumrucker. 1997. Arginine supplementation increases weight gain, depresses antibody production, and alters circulating leukocyte profiles in preruminant calves without affecting plasma growth hormone concentrations. J. Anim. Sci. 75:3019-3025.

Guilhermet, R. G. 1996. Fonctions nutritionnelles et métaboliques de l'arginine. INRA Prod. Anim. 9:265-272.

Hammon, H., and J. W. Blum. 1999. Free amino acids in plasma of neonatal calves are influenced by feeding colostrum for different durations or by feeding only milk replacer. J. Anim. Physiol. Anim. Nutr. 82:193-204.

Hargrove, D. M., G. J. Bagby, C. H. Lang, and J. J. Spitzer. 1988. Adrenergic blockade prevents endotoxin-induced increases in glucose metabolism. Am. J. Physiol. 255:629-635.

Hugi, D., R. M. Bruckmaier, and J. W. Blum. 1997a. Insulin resistance, hyperglycemia, glucosuria, and galactosuria in intensively milk-fed calves: Dependency on age and effects of high lactose intake. J. Anim. Sci. 75:469-482.

Hugi, D., V. D. Bracher, L. Tappy, and J. W. Blum. 1997b. Postprandial hydrogen breath excretion, plasma lactate concentration, glucose metabolism and insulin levels in veal calves. J. Anim. Physiol. Anim. Nutr. 78:42-48.

Kahl, S., T. H. Elsasser, and J. W. Blum. 1997. Nutritional regulation of plasma tumor necrosis factor- $\alpha$ and plasma and urinary nitrite/ nitrate response to endotoxin in cattle. Proc. Soc. Exp. Biol. Med. 215:370-376.

Kahl S., T. H. Elsasser, and J. W. Blum. 2000. Effect of endotoxin challange on hepatic 5'-deiodinase activity in cattle. Domest. Anim. Endocrinol. 18:133-143.

Kaufhold, J. N., H. M. Hammon, R. M. Bruckmaier, B. H. Breier, and J. W. Blum. 2000. Postprandial metabolism and endocrine status in veal calves fed at different frequencies. J. Dairy Sci. 83:2480-2490.

Kenison, D. C., T. H. Elsasser, and R. Fayer. 1991. Tumor necrosis factor as a potential mediator of acute metabolic and hormonal responses to endotoxemia in calves. Am. J. Vet. Res. 52:1320 1326.

Kinsbergen, M., R. M. Bruckmaier, and J. W. Blum. 1994. Metabolic, endocrine and hematological responses to intravenous $E$. coli endotoxin administration in 1-week-old calves. J. Vet. Med. A 41:530-547.

Kirchgessner, M. 1997. Tierernährung. 10. Aufl., Verlags Union Agrar, DLG Verlag, Frankfurt, Germany.

Kirk, S. J., and A. Barbul. 1990. Role of arginine in trauma, sepsis and immunity. J. Parenter. Ent. Nutr. 14 (Suppl. 5):226s-229s.

Klasing, K. C. 1988. Nutritional aspects of leukocytic cytokines. J. Nutr. 118:1436-1446.

Knowles, R. G., S. J. Beevers, and C. I. Pogson.1986. The role of glucagon, insulin and glucocorticoid hormones in the effects of sublethal doses of endotoxin on glucose homeostasis in rats. Biochem. Pharmacol. 35:4043-4048.

Merriam, G. R., and K. W. Wachter. 1982. Algorithms for the study of episodic hormone secretion. Am. J. Physiol. 243:E310-E318.

Reeds, P. J., and T. W. Hutchens. 1994. Protein requirements: from nitrogen balance to functional impact. J. Nutr. 124:1754S-1764S.

Sano, H., S. Nakamura, S. Kobayashi, H. Takahashi, and Y. Terashima. 1995. Effect of cold exposure on profiles of metabolic and endocrine responses and on responses to feeding and arginine injection in sheep. J. Anim. Sci. 73:2054-2062.

SAS Institute Inc. 1994. Introductory Comparison of the GLM and Mixed Procedures. SAS Inst. Inc., Cary, NC.

Sugano, M., N. Ishiwaki, Y. Nagata, and K. Imaizumi. 1982. Effects of arginine and lysine addition to casein and soya-bean protein on serum lipids, apoproteins, insulin and glucagon in rats. Br. J. Nutr. 48:211-221.

Swanson, D. R. 1990. Somatomedin C and arginine: Implicit connections between mutually isolated literatures. Perspect. Biol. 33:157-185.

Toullec, R. 1988. Alimentation du veau de boucherie. Pages 185-199 in Alimentation des Bovins, Caprins et Ovins. R. Jarrige, ed. INRA, Paris.

Visek, W. J. 1986. Arginine needs, physiological state and usual diets. A reevaluation. J. Nutr. 116:36-46.

Williams, A. P., and D. Hewitt. 1979. The amino acid requirements of the preruminant calf. Br. J. Nutr. 41:311-319.

Wu, G., C. J. Meininger, D. A. Knabe, F. W. Bazer, and J. M. Rhoads. 2000. Arginine nutrition in development, health and disease. Curr. Opin. Clin. Nutr. Metab. Care 3:59-66.

Yelich, M. R., and J. P. Filkins. 1982. Insulin hypersecretion and potentation of endotoxin shock in the rat. Circ. Shock 9:589-603. 